\title{
Life Cycle Assessment (LCA) and Wind Power Generation: Application of the Methodology and the Generator to Power System
}

\author{
Mozart Tavares da Silva ${ }^{{ }^{*}}$, Vanessa Zadorosnei Rebutini ${ }^{1}$, Fabrízio Nicolai Mancini ${ }^{1}$ \\ ${ }^{1}$ Faculdade Estácio de Curitiba, Curitiba, Brazil.
}

\begin{abstract}
Sustainability and economics are current issues in the generation of electricity. The energy matrix is diversified and some forms have stood out, such as wind. Some tools have been developed to improve project efficiency, one of which is Life Cycle Assessment (LCA). This presents solidity when assisting projects financially and environmentally, evaluating materials and processes. The present study aimed to analyze the application of LCA in a wind power plant. After searching the main databases and using filters, the analysis was developed from the information of an article that described the application of the LCA to a wind power plant using computational simulation, providing an overview of the production and potential environmental impacts for the process manufacturing, parts maintenance, disposal and recycling at end of lifespan. The phases, steps and the threshold diagram of the LCA system were observed. The results showed a high rate of reuse/recycling of some materials and significant reductions in emissions, financial costs and abatement of environmental payback if the materials were recycled at the end of lifespan. Recycling has shown positive environmental aspects and a significant cost reduction, allowing the expansion of markets and optimization of wind projects.
\end{abstract}

Keywords: Life Cycle Assessment (LCA), Wind farm, Sustainability.

\footnotetext{
*Author for correspondence: mozart.tavares.fg@ hotmail.com
} 


\section{INTRODUCTION}

The use of the wind to generate work is not a recent phenomenon and has the purpose of facilitating human daily life ${ }^{1}$, providing electric energy for small demands or on a larger scale to distribute to the national transmission system ${ }^{2}$. Although considered clean because it does not emit waste that contributes to global warming, wind power generation has other types of environmental impacts that become considerable as the size and number of the wind turbines implanted increases ${ }^{3}$, for example extensive land use, noise, visual impacts and bird mortality ${ }^{4,5}$.

Several countries currently have considerable wind power production from horizontal motor wind turbines, installed in land or sea ${ }^{6}$. The evolution of technology led to equipment and processes optimizations, maximization of energy production and reduction of product cost ${ }^{7}$. The peculiarity of wind speed variation demands technological adaptations in the generators to deliver electrical energy to the network with constant characteristics, which provides efficient generation results ${ }^{8}$.

With increasing awareness of the importance of sustainable development, the processes and products have received attention based on the possible influence they could exert on existing environmental impacts. Lifecycle and analysis tools, such as Life Cycle Assessment (LCA), have been developed to assess the environmental impacts during the lifespan of a product ${ }^{9}$. It is understood then that any product or service provokes, by its own existence, effects and results in the environment that can be tied to the own productive system (means or method by which the product is made), the materials that it consumes (inputs or raw material used to make the product), its actual use, its disposal or final destination - elements that describe the product life cycle ${ }^{10}$.

Despite being considered a source of clean energy, wind power generation has details in its life cycle that must be carefully considered, for example: the processes of extraction of raw material, the use of the devices as well as their disposal or reuse. Such care is directly related to the actual degree of emission of pollutants that these processes present, which raises questions about the real environmental status of this form of energy generation.

Aiming to improve the environmental performance of products during the various stages of its lifespan, LCA is an internationally recognized management system (ISO 14040: 2006 and 14044: 2006) that contributes to public policies to reduce emissions and guide measures of reuse and recycling in several countries ${ }^{11}$. It is a methodology applied since the $60 \mathrm{~s}^{12}$ and allows to model a production system with criteria and requirements of sustainability, serving as a database for the formation of norms and environmental regulations ${ }^{13}$.

In Brazil, despite the existence of the local norm for the subject, the use of LCA is still less widespread ${ }^{13,14}$ and a considerable effort is needed to reverse such situation ${ }^{14}$. Research has shown that, although Brazil has evolved significantly in recent years, the application of LCA is still low compared to countries such as those of the European Union, NAFTA and APEC ${ }^{14}$.

ABNT, through NBR 14040 and NBR 14044, presents the principles and structure of the LCA, requirements and guidelines respectively ${ }^{15,}{ }^{16}$. Thus, it is observed that this is composed of four phases or stages, as described below $9,17,16$;

- Objective and scope definition: description of the product system to be studied, its purpose, extent and limits; specification of the intended application, target audience and functional unit.

- Inventory analysis: it includes the data collection and the procedures for the matter and energy inputs and outputs quantification. 
- Impact assessment: evaluates the importance and magnitude of environmental aspects observed in the inventory, results in interventions through indicators.

- Interpretation: evaluation of the study from the established objectives, analysis of the results, formulation of conclusions and recommendations for the reduction of the environmental impacts potentially generated by the system.

The LCA is a methodology used to observe complex environmental issues, it produces numbers that enable decisions in favor of established objective ${ }^{16}$. Despite the need to follow the steps described for application of this method, which results in a considerable consistency, some adaptations are acceptable depending on the particularities of the object and environment ${ }^{14}$. However, these particularities have the consequence of limitations such as the reduction of the applicability of the results obtained, the production of an inconsistent database to subsidize information and the lack of harmonization of the existing database according to the different criteria ${ }^{18,16}$.

From the limitations listed, it is understood that there are great challenges for the consolidation of this methodology in Brazil, especially considering that there is a primary need to build a database with the characteristics of the country's technologies and that there are local peculiarities that need attention. However, in view of the need to remedy these limitations and that the application of the method itself is a way of doing so, it is understood that the application of this method in studies will make it possible to improve the situation. Such a conclusion can be justified by the international scenario, where the method is applied and one can observe the structuring of the methodology, the consequent improvements of the environmental indicators and the reliability of the results ${ }^{18}$.

\section{OBJECTIVE}

Considering that sustainable development is the current issue, the present study aimed to analyze the application of the LCA in a wind power plant, delineating the application of its phases to the plant and the wind turbine. Also, the results obtained were analyzed through the application of the technique, showing the advantages and disadvantages seeking to contribute with the expansion of the knowledge about the topic.

\section{METHODS}

A bibliometric survey was carried out in the largest databases, using filters to approximate the results to the subject studied. From the articles obtained, the analysis of the application of the LCA was developed from the information present in a study that describes such application to a wind power plant through computational simulation under corroboration of the current literature. After the formulation of the phases and phases of the LCA, this simulation allowed the analysis of the phases and components of some elements of a wind power plant, the elaboration of potential environmental impacts according to the manufacturing process, maintenance, disposal and recycling. These elements have provided the means to provide an overview of the effects of energy production, from the choice of raw materials of the parts of the wind power plant to their destination, at the end of their lifespan. 


\section{RESULTS}

The analysis was developed using only free and available information in the literature - one of the articles was used as a database for the construction of the work and the others were portrayed in a timely manner. The article used as a pillar belongs to the research hall of the company Vestas Wind Systems A/S, considered as a reliable source of data for being a manufacturer of the equipment studied and for presenting, for more than a decade, studies, results and solutions for the application of LCA in wind generation ${ }^{19}$.

The life cycle analysis applied in the study above mentioned used the process of observing the cradle to the grave of a wind plant built with Vestas turbines, model V110-2.0MW. The wind set was virtually arranged for the simulation of results with the objective of providing an overview of the energy production using Gabi DfX software, specifically developed for this type of analysis. Potential environmental impacts were calculated for each component of the turbine according to the manufacturing process, parts maintenance, disposal specifications and steps to recycle the products at the end of their useful lifespan.

Subsequently, the four phases of the LCA and its stages were described, namely:

\section{Objective and Scope of the Study}

The objective of the study was to evaluate the environmental impacts associated with the production of electric energy in a wind farm of 50MW onshore, composed of twenty five (25) wind turbines, model V110-2.0MW of own manufacture. This configuration represents a typical wind farm model and the evaluation ranges from the extraction of raw material to the assembly of the wind farm. The scope of this LCA study includes the analysis of the cradle to the grave for the production of electric energy, which includes the time of extraction of raw materials from the environment to the production of mounted wind turbines; as well as logistics, plant maintenance, life cycle management to the point where the plant is disposed of and its parts are returned to the environment, or recycled and reused.

\section{Cycle Inventory and Environmental Impacts}

GaBi DfX software and the project-related data provided were used to model the scenarios, generate the life cycle inventories and the impact assessments that underpinned the study. The models obtained through the simulation were presented consistent with that observed in previous studies of the company ${ }^{20,21}$. Life cycle modeling begins with a list of materials that contains a partial turbine tree, where each finished part is associated with a material, manufacturing process, and country of origin. Such detailing is extremely extensive, as the V110-2.0MW turbine can be represented by approximately 25,000 distinct parts. Modeling all these components may be impractical, however, using the GaBi DfX software allows the information from all these parts to be launched in the system so that the system takes care of mapping the manufacturing processes and the materials used in them.

The environmental impacts assessed in this study include global warming, depletion of abiotic resources, as well as other indicators with no direct impacts, such as water recycling and reuse. The categories of environmental impacts raised during this study represents the possible impacts likely to arise from a wind system, such as those associated with the production, extraction of raw material, manufacture and recycling of metals. For this example, it is shown that the turbine itself is made up of $87 \%$ of metals and other materials that together make up the plant, but on a smaller scale, such 
as concrete, polymers and composite materials. In general, LCA does not address environmental concerns of a different nature, such as the potential impacts caused by land use, noise, and impacts to flora and fauna. To circumvent this gap, other environmental management techniques should be applied in parallel to the LCA, such as the Environmental Impact Study (EIS).

\section{Interpretation}

Data sets were qualitatively evaluated against the quality requirements established for the inventory data (coverage, accuracy, completeness, representativeness, consistency, reproducibility). A great deal of emphasis is placed on the final destination of the elements after the completion of the life cycle. The recycling of materials was pointed as a differentiating element of the amount of possible reductions for a process, making this modality of energy generation more attractive for implementation. The study carried out by Vestas shows that all major components contained in a wind power plant, around 98\%, are passive recycling. Among the materials that are passive recycling, we can mention tower sections, cast iron frames and other important components such as generator, gearbox and cables, which are recycled by approximately $95 \%$. There are parts, such as copper, steel, iron and others, which have the same reusability rates, both from the environmental aspect and their acquisition cost ${ }^{22}$.

Regarding the results related to the categories of impacts (Table 1), the greatest damage generated by the abiotic elements is recorded during the extraction and manufacturing of materials that are subsequently used in the manufacture of important components such as nacelle, generator, gearbox. The percentage of reutilization offers to the environment a credit of $70 \%$ referring to damages that are no longer generated to the environment when compared to the extraction process considering the accomplishment of all stages of production of new components.

The same analysis and considerations were made for the fossil abiotic resources: the greatest impacts are recorded in the process of extraction of the raw material. However, the process of reuse of the parts at the end of the lifespan represented an environmental credit estimated at $30 \%$ when compared to the production of material by extraction.

With regard to the emission of sulfur dioxide and ozone, these emissions cause impacts related to the reduction of the $\mathrm{pH}$ of rainwater and cause acid rain. As with the previously mentioned steps, the final phase of life is responsible for the reduction of approximately $27 \%$ of emissions to the environment when compared to the process of extraction of the raw material.

Another concern is the emission of phosphate in the environment, which can generate the process of eutrophication (elevation of the nutrient level that causes damage to the ecosystem). This effect is observed in the production of wind turbine blades, which are composed of fiberglass. In the reuse stage, this category represents a relatively small impact reduction index on the environment, close to $6 \%$ less emissions when compared to the primary process.

The index that indicates the level of intoxication of fresh water, soil and air by the emission of polychlorinated dioxins or heavy metals is also related to the extraction of materials for the construction of the tower, blades and foundation of the tower. The associated reuse process has a small index of credits with the environment, around 9\% of benefits when considering the primary production process.

The category that deals with the emission of greenhouse gases emitted during the process of extraction and production of materials such as iron, fiberglass used in blades, steel and copper, are responsible for the release of approximately $91 \%$ of 
carbon dioxide. In the reuse cycle, the environment benefits from a reduction of approximately $31 \%$ in emissions when compared to the complete process, either raw material or finished product.

Human toxicological potential and marine aquatic ecotoxicological potential are categories that release substances toxic to air, soil and water. Like the previous categories, the process of extraction of raw material and the process of production of components of nacelle and tower, copper and aluminum are the main responsible for the toxic emissions to the environment. At the end of the product's lifespan, both categories have a significant emission reduction of approximately $79 \%$ and $72 \%$, respectively.

The emission of photochemical oxidants allows the creation of low level oxidants in the environment. The manufacturing process of nacelle components, foundation and blades of the wind generator is responsible for the release of these gases into the environment and reuse of the components results in a credit of approximately $31 \%$ to the environment.

Finally, the category that addresses the levels of environmental toxic emissions to the environment, which releases pollutants, also presents the manufacturing process with greater impact by the emission of heavy metals and offers the environment a credit of $2 \%$ if reuse is considered.

Lastly, the categories that addresses the ecotoxic emissions levels to the land environment, which emit pollutants for the environment, also present the manufacturing process with larger impact for heavy metal emission and offer to the environment the $2 \%$ credit if reuse is considered.

Table 1 - Categories observed in the Vestas study

\begin{tabular}{ccc}
\hline Categories & Reduction forms & Environments Credits \\
\hline Abiotic elements & Reuse in end of lifespan & $70 \%$ \\
\hline $\begin{array}{c}\text { Fossil Abiotic elements } \\
\text { oxide }\end{array}$ & Reuse in end of lifespan & $30 \%$ \\
\hline $\begin{array}{c}\text { Emission of sulfur dioxide and zinc } \\
\text { Phosphate emission }\end{array}$ & Reuse in end of lifespan & $27 \%$ \\
\hline $\begin{array}{c}\text { Freshwater, air and soil poisoning - } \\
\text { Emissions of polychlorinated } \\
\text { dioxins }\end{array}$ & Reuse in end of lifespan & $6 \%$ \\
\hline $\begin{array}{c}\text { Emission of Gases (Greenhouse } \\
\text { Effect) }\end{array}$ & Reuse in end of lifespan & $9 \%$ \\
\hline $\begin{array}{c}\text { Potential Toxicological human and } \\
\text { ecotoxicological marine }\end{array}$ & Reuse in end of lifespan & $31 \%$ \\
\hline Photochemical oxidants & Reuse in end of lifespan & $79 \%$ and $72 \%$ \\
\hline Toxic release to the environment & Reuse in end of lifespan & $31 \%$ \\
\hline
\end{tabular}

The conclusions of the study indicated data that show a great potential of degradation for the effects related to the production phase of the equipment. On the other hand, there is a great compensating potential in the actions that involve the maneuvering methods for the recycling of the materials after the end of its useful lifespan, which has its reinsertion in the production. The other stages (operation, maintenance and installation) have not been expressively considered, since the transport phase, despite having a significant impact, is not directly linked to the wind power plant.

\section{DISCUSSION}

Considering what has been presented in the Results on the development of the researches in the present work, it is emphasized that the analysis follows the last 
established guidelines - the analysis of the benefits of the application of the technique regarding the advantages and for the maintenance of the natural resources. Although presented briefly by the study and also described in the previous chapter, the useful lifespan of the wind system as being 20 years has been considered. It should be noted that this period is commonly used in literature, although there are reports of longer intervals ${ }^{23,24}$.

As described in the Results chapter, similar subdivisions presented in the VESTAS study were found in other studies ${ }^{23,25}$. There are common processes and stages in these studies, despite the necessary considerations on the particularities mentioned in the description of the method (location of study, regionalism, specific database, etc.) 26 .

The use of a software to model the results is aimed at reducing the detail of the origins of the pieces that make up the equipment and makes the generalization of the results possible by disregarding the characteristics of facilities of the wind plate. This procedure has already been observed in literature with the purpose of expanding the studies of the area and providing extrapolations to quantify the projects of wind plants 27 .

As for the phases of higher impact, it was shown that there is a great potential for degradation related to the production phase of the equipment, which includes initial phases such as the extraction of raw material. Such results were also found in other studies that demonstrated and detailed emissions according to the studied phase ${ }^{23,28}$.

The categories of impacts available in this LCA also report as common to area studies 24,19 . The results obtained for the categories of impacts described in the previous chapter, regardless of the specificity of the category, point to the possibility of reduction in emissions or to credit with the use of this type of energy generation. This result is mainly observed when considering changes in the actions of the last phase of the technique, end of lifespan, which establishes the final destination of the elements, devices and equipment of the plant. The necessary actions identified in the study are the reuse and recycling of materials, which resulted in reductions of $2 \%$ to $91 \%$ in emissions or credits in emissions.

Such information is corroborated by studies that found $12 \%$ to $89 \%$ reduction or emission credits ${ }^{29,30,25,24}$. If the changes are not observed, the study shows that this form of energy generation is not as 'clean' for the environment as one might imagine. The argument emphasizes that renewable forms of energy generation, despite not directly containing carbon as a result of the process, are pollutants because they present large emissions when considering their entire manufacturing process, assembly, installation and the materials that make up their equipment ${ }^{29,31}$.

Regarding the emissions mentioned earlier, some connections have been made: some primary elements, or raw materials, may hold a greater proportion in the responsibility of these emissions. As described in the results, the metals that make up the wind turbines trigger great consequences in the extraction phase, for example copper, and recycling would represent a significant reduction in emissions. Such notes are corroborated by literature, which points out such responsibility to these elements in the most diverse phases of the LCA, as well as if applied to similar systems to those studied here ${ }^{23,32}$

Other metals and structures also have significant contributions, such as insulation and power system components. However, as already presented, the contributions of such elements to the wind farm have not been widely studied. The information found only indicates that, according to certain types and for other applications, the insulation presents emission levels ${ }^{33}$, that the power components have their contribution to the increase of emissions of pollutants in their phases of the lifespan and that the reuse of all these elements means credits in the emissions accounting ${ }^{34}$. 
Although only referred to in the baseline study, primary elements (metals and other compositions) hold a significant fraction of manufacturing costs due to procedures such as extraction. It is noted that these elements have a high degree of reusability. Therefore, it is considered that, in addition to positive environmental consequences, their recycling would imply a significant reduction of the costs of the stage. This is corroborated by studies that have shown rates reductions in costs higher than $10 \%$, considering constructive aspects - the first phase of the technique ${ }^{30}$. In addition to the reuse and recycling aspect, some studies address the substitution for components that are easier to recycle as a long-term solution to help reduce emissions and system costs - reductions that can reach rates 30\% higher than the values already reported for emissions and significant values for overall costs ${ }^{35,32}$.

As for the equipment referred to as the initial observation objective, it was found that the generator contributes about $60 \%$ of the expected emissions to the nacelle ${ }^{28}$, with copper being the main element of this statistic when the equipment is applied to a wind turbine ${ }^{36}$. The power system devices, as well as the insulation, have a large part in the environmental impact observed for the nacelle structure ${ }^{28}$. In spite of the importance of the raw materials capacity of these components, few sources of information were found that deal specifically with these materials.

The presented study approached a certain type of turbine size, since the intention was to analyze the LCA technique from a larger capacity wind farm. However, in literature it is possible to observe analysis of the technique for several types of aerogenerators, as well as for different sizes of installations - even for case studies with a tower. Out of these, some approach comparisons between the different structures, so as to point out relevant data in relation to the analysis of the present work have been carried out. Considering the aspects of environmental emission and impact, it is proven that larger scale turbines are environmentally more sustainable than micro installations ${ }^{24,37,36}$. The arguments presented vary considering the values of directly related emissions, credits obtained due to changes in structure and production capacity - which directly reduces other emissions and are 'avoided' due to the operation of this system.

It was observed in this chapter, from the information of the main article and study found, that the method was effectively applied in wind power generator system, more specifically in wind generator. The LCA is outlined and presented for the device, the composition and parameters of each of its phases, as well as its results. The information presented from the main article was corroborated by the studies published so far, proving its validity as descriptor of the technique for wind generator.

As for the technical elements applied to the generator and power devices of the wind generator, it was not possible to establish such a description due to the lack of data that allowed such structuring with the due reliability and no studies have been found that allowed the extraction of data of this nature so as to fill this gap and establish a minimum analysis of the application of the technique for these components.

The results presented by the main article according to the analysis were also corroborated by the studies published so far. Considering only the aerogenerator, the results have shown that the components of the turbine, nacelle and tower are the ones that contribute most to the environmental impact indicators. It has been observed that copper present in nacelle is one of the elements that contributes most to environmental degradation if destined for landfill, and that the equipment of the power system has its parcel if unduly segregated. It has also been observed that there is a compensatory effect when considering the reuse or recycling of plant materials, a factor that significantly affects all the impact categories studied.

This compensatory effect results in a series of consequences, as it can determine significant changes in the structuring process of wind power generation and its subprocesses - manufacturing, production, maintenance and disposal. Although efficiently identified in scientific studies, such adjustments need the means to be put 
into practice: the policies to encourage the main processes and the secondary systems, related to the procedures observed in the phases of the LCA applied to the wind generator, such as end of lifespan, reuse and recycling.

It is clear from the content of this paper that LCA has many advantages in its application: In addition to observing environmental factors, achieving goals, reducing pollution and sustainable development, the analysis can contribute to the development of markets, the economy and politics. Like the present study, in establishing the benefits of the form of generation, this provides arguments for the investment in this type of technology. By establishing the benefits of reuse and recycling adjustments, this triggers new projects and the heating of markets not currently recognized. As a main factor, these results are of fundamental importance for the wind power project area, by influencing actions in the short, medium and long term.

As for the disadvantages, they can be said to be directly related to the disadvantages of the technique itself - previously described and presented as limitations. Although we consider these disadvantages to be real and, to some degree to cause a reduction in the efficiency of the technique, it is clear that they are feasible. This can be observed in the present study, in the main article and other studies that have established predictions by means of software and other maneuvers to minimize the effects of limitation of the technique.

\section{CONCLUSION}

The present work has to determine the LCA as an efficient and important tool for the identification of the real impact that a process can represent for society and the environment. Such a view allows to establish contouring, substitution or compensation measures for the foreseeable damages. When analyzing a source of "clean" energy generation as a wind power is called, one hears only the positive points that this source of energy can offer to the environment in its operation. This study has allowed to identify that the stages that precede and those that follow at the end of the useful lifespan, the phase of operation of a wind power plant can present risks as much as other sources of generation of electricity, either in the stages of extraction of raw material for making of their components or in the adjustments that need to be made at the premises where the plant will be installed

It is obvious that many of the damages caused to nature are seen as harmful to nature and unfortunately we do not consider the option of leaving them aside. For example, in order to build a wind, hydro or thermal power plant, it is necessary to use land that serves as a shelter for animal or plant species. In other cases, such as the extraction of iron ore, copper, aluminum and the like, when life cycle analysis applied in the correct way, the changing of this process is able to bring countless benefits to nature. These facts are verified by the data analyzed in this study, which present reductions in the percentage of degradation of the environment by the reuse of primary components such as iron ore, copper and aluminum.

\section{REFERENCES}

1 - Salles, A. C. N. D. Metodologias de análise de risco para avaliação financeira de projetos de geração eólica em Tese - Programa De Pós-Graduação, Rio De Janeiro: UFRJ, 2004.

2 - Agência Nacional De Energia Elétrica, ANEEL, 2005. [cited 2017 Feb]. Available from: http://www2.aneel.gov.br/aplicacoes/atlas/download.htm.

3 - Rampinelli, G. A.; Rosa Junior, C. G. Análise da Geração Eólica na Matriz Brasileira de Energia Elétrica. Revista Ciências Exatas e Naturais. 2012, 14(2). 
4 - Cresesb. Centro De Referência Para Energia Solar E Eólica Sérgio Brito. 2015. [Online]. Available from: http://www.cresesb.cepel.br/index.php?section=com_content\&lang=pt\&catid=3.

5 - Pontifícia Universidade Católica do Rio Grande do Sul - PUC-RS.. CE-EOLICA, 2017. [cited $2017 \mathrm{fev}$ ]. Available from: www.pucrs.br/ce-eolica/.

6 - Rüncos, F., Carlson R., Kuo-Peng P., Voltolini H., Batistela N. J., 2017. [cited 2017 fev]. Available from: http://catalogo.weg.com.br/files/wegnet/WEG-geracao-de-energia-eolicatecnologias-atuais-e-futuras-artigo-tecnico-portugues-br.pdf.

7 - Filho A. S., Cardoso J. G. Energia eólica: tipos de geradores e conversores usados atualmente, 2014. [cited $2017 \mathrm{fev}$ ]. Available: www.ieee.org.br/wp-content/uploads/.../artigodo-espaco-do-IEEE-maio-2014.pdf.

8 - Freitas W., França A. M., Junior J. C. M. V., Da Silva L. C. P. Análise comparativa entre geradores síncronos e geradores de indução com rotor tipo gaiola de esquilo para aplicação em geração distribuída, 2005. Sba Controle \& Automação - Sociedade Brasileira de Automação, $16(3)$

9 - De Assis B. B. Avaliação do Ciclo de Vida do produto como ferramenta para o desenvolvimento sustentável. Trabalho de Conclusão de Curso - Engenharia de Produção. 2009.

10 - Coltro L. Avaliação do Ciclo de Vida como Instrumento de Gestão,” 2007. [cited 2017 mar]. Available from: http://cetea.ital.sp.gov.br/publicacoes/adi_25/files/assets/basichtml/page1.html.

11 - . Empresa Brasileira de Pesquisa Agropecuária - EMBRAPA, 2013. [cited 2017 apr]. Available from: https://www.embrapa.br/busca-de-noticias/-/noticia/1501997/embrapaoferece-treinamento-em-avaliacao-de-ciclo-de-vida.

12 - Ribeiro F. M. Inventário de ciclo de vida da geração hidrelétrica no Brasil - Usina de Itaipu: primeira aproximação. Dissertação de Mestrado, São Paulo, 2003.

13 - Filho O. C., Junior N. L. S., Luedemann G. Instituto de Pesquisa Econômica Aplicada IPEA, 2016. [cited 2017 apr]. Available from: http://www.ipea.gov.br/portal/index.php?option=com_content \&view=article\&id=28041.

14 - Barbosa Junior A. F., Morais R. F., Emerenciano S. V., Pimenta H. C. D., Gouvinhas R. P. Conceitos e Aplicações da ACV no Brasil, 2008. Revista Ibero-Americana de Estratégia, 7(1).

15 - Associação Brasileira de Normas Técnicas ABNT, 2009. [cited 2017 mar]. Available from: http://licenciadorambiental.com.br/wp-content/uploads/2015/01/NBR-14.040Gest\%C3\%A3o-Ambiental-avaliac\%C3\%A3o-do-ciclo-de-vida-principios-e-estrutura.pdf.

16 - Associação Brasileira de Normas Técnicas ABNT. 2009. [cited 2017 mar]. Available from:

https://docs.google.com/viewer?a=v\&pid=sites\&srcid=ZGVmYXVsdGRvbWFpbnxwYWZhZ XNwfGd4OjUyZmM5YWQzYTg2YmZjZDc.

17 - Marcal L. M., De Francisco A. C., Da Luz L. M., Piekarski C. M. Fundamentos da Análise do Ciclo de Vida , 2013. XXXIII Encontro Nacional de Engenharia de Produção, Salvador/BH.

18 - Zocche L. A Identificação das limitações da ACV sob a ótica de pesquisas acadêmicas. Dissertação - Programa de Pós Graduação em Engenharia de Produção: UEPG. Ponta Grossa, 2014.

19 - Thompson R. C. Carbon and Energy Payback of Variable Renewable Generation. Tese de Doutorado, Escócia, 2014.

20 - Vestas. Vestas Life cycle assessment of offshore and onshore sited wind power plants based on Vestas V90-3.0MW turbines. Vestas Wind Systems A/S, 2005. 
21 - Vestas. Vestas Life cycle assessment of offshore and onshore sited wind power plants based on Vestas V90-3.0MW turbines. Vestas Wind Systems A/S, 2006.

22 - Vestas. Life Cycle Assessment of Electricity Production from an onshore V110-2.0 MW Wind Plant, p. 129, Dinamarca, 2015.

23 - Ardente F., Beccali M., Cellura M., Brano L. Energy performances and life cycle assessment of an Italian wind farm, 2008. Renewable and Sustainable Energy Reviews, 12:200-217.

24 - Greening B., Azapagic A. Environmental impacts of micro-wind turbines and their potential to contribute to UK climate change targets, 2013. Energy, 59:454-466.

25 - Uddin S., Kumar S. Energy, emissions and environmental impact analysis of wind turbine using life cycle assessment technique, 2014. Journal of Cleaner Production, 69:153-164.

26 - Zimmermnn T. Parameterized tool for site specific LCAs of wind energy converters, 2012 [cited 2017 fev]. International Journal of Life Cycle Assessment.

27 - Campolina J. M., Sigrist C. S. L., Moris V. A. S. Uma revisão de literatura sobre softwares utilizados em estudos de Avaliação de Ciclo de Vida, 2015. Revista Eletrônica em Gestão, Educação e Tecnologia Ambiental, 19(2):735-750.

28 - Wang W. C., Teah H. Y. Life cycle assessment of small-scale horizontal axis wind turbines in Taiwan, 2017. Journal of Cleaner Production, 141:492-501.

29 - Garret P., Ronde K. Life cycle assessment of wind power: comprehensive results from a state-of-the-art approach, 2012. International Journal of Life Cycle Assessment.

30 - Schau E. M., Traverso M., Finkbeiner M. Life cycle approach to sustainability assessment: a case study of remanufactured alternators, 2012. Journal of Remanufacturing, 2(5).

31 - Sevencan S., Ciftcioglu G. A. Life cycle assessment of power generation alternatives for a stand-alone mobile house, 2013. International Journal of Hydrogen Energy, p. 14369-14379.

32 - Rashedi A., Sridhar I., Tseng K. J. Life cycle assessment of $50 \mathrm{MW}$ wind firms and strategies for impact reduction, 2013. Renewable and Sustainable Energy Reviews, 21:89-101.

33 - Garcia B. A., Goncalves M., Vera T. O. Life Cycle Assesment (LCA) study of a vehicle wiring, 2011. Afinidad, v. 68.

34 - Benton K., Yang X., Wang Z. Life cycle energy assessment of a standby diesel generator set, 2017. Journal of Cleaner Production, 149:265-274.

35 - Andersen N., Eriksson O., Hillman K., Wallhagen M. Wind Turbines' End-of-Life: Quantification and Characterisation of Future Waste Materials on a National Level, 2016. Journal Energies, v. 9.

36 - Smith C., Burrows J., Schneier E., Young A., Smith J., Young T., Gheewala S. H. Comparative Life Cycle Assessment of a Thai Island's diesel/PV/wind hybrid microgrid, 2015. Renewable Energy, 80:85-100.

37 - Pascale A., Urmee T., Moore A. Life cycle assessment of a community hydroelectric power system in rural Thailand, 2011. Renewable Energy, 36:2799-2808.

38 - Rodrigues M. A. C. Diagnóstico de Avarias em Sistemas de Conversão de Energia Eólica. Dissertação - Mestrado em Engenharia Eletrotécnica e de Computadores: Universidade do Porto, 2017.

39 - Trajano R. C., Barros V. C. A. Estudo Preliminar de Implantação de Parque Gerador Eólico," em Trabalho de Conclusão de Curso, 2009.

40 - Alegria I II. Parque Eólico Alegria, 2011 [cited 2017 fev]. Available from: http://www.parqueeolicoalegria.com.br/energia-eolica.

41 - Ackermann T. Wind Power in Power Systems. Inglaterra: John Wiley \& Sons Ltd, 2005. 
42 - Agência Brasileira de Desenvolvimento Industrial ABDI, 2014 [cited 2017 fev]. Available from:

http://www.abdi.com.br/Estudo_Backup/Mapeamento\%20da\%20Cadeia\%20Produtiva\%20da $\% 20$ Ind $\%$ C3\%BAstria\%20E\%C3\%B3lica\%20no\%20Brasil.pdf.

43 - Alves J. J. A. Estimativa da Potência, Perspectiva e Sustentabilidade da Energia Eólica no Estado do Ceará. Tese - Pós-Graduação em Recursos Naturais: Universidade Federal de Campina Grande, 2006.

Received: December 21, 2017; Accepted: August 01, 2018 